\title{
for(e)dialogue
}

Department of Media and Communication

Volume 1, Issue 1: New Directions in Media Research 2015

A Poststructuralist Review of Selfies: Moving Beyond Heteronormative Visual Rhetoric

Patricia Routh

(p. 4-14)

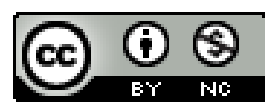

This work is licensed under a

Creative Commons Attribution- Non Commercial 4.0 International License

March 2016 
Volume 1, Issue 1: New Directions in Media Research 2015

\section{A Poststructuralist Review of Selfies: Moving Beyond Heteronormative Visual Rhetoric.}

\section{Patricia Routh}

Abstract: Mobile devices can instantly create and distribute a digital self-portrait, or 'selfie' across a myriad of social networks. The word 'selfie' summarises a particular kind of cultural and photographic practice that is motivated by a combination of the agency and aspirational biases of the selfie producer and where they prefer to share on social networks. With a specific focus on gendered selfie production, this paper aims to explore the relevant theories for gender identity within online communities in which selfies are shared. From a theoretical starting point, firstly this paper employs the poststructuralist theories (Deleuze and Guattari, 1980) as interpretative filters for a decisive understanding of the inner "rhizome" of an individual's ideal of "becoming". This paper argues that the embodied human subject is transformed by self-exploration with the production and distribution of their selfies.

Keywords: selfies, gender, identity, production, embodiment

\section{Introduction}

This paper is concerned with the 'selfie' phenomenon: a shorthand term for the rapid popularity around the world in the production and circulation of self-generated digital photographic portraiture, spread primarily via mobile devices and social media. Among academic researchers from diverging disciplines that study selfies, there can often be conflicting opinions of/views of what actually constitutes a selfie. Often broadly integrating self-portraits made prior to advent of actual selfie technology, (camera phone and social media), or even portraits taken by a professional photographer, as to what constitutes a selfie. The Oxford Dictionary definition of a selfie defines the term to signify, 'a photograph that one has taken of oneself, typically one taken with a smartphone or webcam and shared via social media (Allen, 2013). The definition offered by Oxford provides a starting point, but the definition tells us nothing about the use, purpose, or meaning of selfies for those that produce them (Warfield, 2014a). More precisely, a selfie is an object created by a mobile device designed to envisage human agency. Through an assemblage of non-human agents, a selfie is created, displayed, distributed, tracked, and monetised (Senft, 2015). A selfie is also a performativity gesture, distributing varied visual messages to diverse online communities, and individuals (Frosh, 2015). 
Volume 1, Issue 1: New Directions in Media Research 2015

The origins of the behaviours and attitudes surrounding gendered performativity within selfie production have existed and been cultivated in the western world for some time (Walker Rettberg, 2014). Western models of narcissism and hegemony, the invention of the mirror, the invention of the consumer camera and the availability and pervasiveness of gendered gaze in media, influence the gendered performances within selfie-making and also the subsequent reactions to selfie production. Equally as important to selfies, and what truly distinguishes them from other self imaging technology, is the mediated affordances of mobile camera devices and social networks (Warfield, 2014b). Through selfie production, groups of individuals, once marginalised in society by the dominant commoditised cultural visual rhetoric (ethnic minorities, women, homosexuals, transgender and non-binary), now have the power to control their image in ways that break from the societal norm. With a specific focus on gendered selfie production, both heteronormative and alternative performativity, this paper aims to theorise the selfie as a potential tool for positive transformation. It concentrates on the ways gender self-presentation is formed through an arrangement of affirmations and feedback derived from the online social groups in which they are distributed and shared.

\section{Literature}

This is a review of the key concepts, readings, and theories that will delineate the relationship between westernised self-image making and the current phenomenon of selfie production. It will establish the framework for this paper by providing both historical and contemporary thoughts about attitudes and behaviours surrounding gendered selfie production. The literature review is divided into three sections covering the key influences of selfie production related to this study: gender performativity, embodiment and digital visual objects. To expand upon the understanding of selfies as both a performative act and image, the selfie connects with core concerns across a range of the interdisciplinary areas of art, psychology, social science, media studies and philosophy (Senft, 2015). Drawing on the post-structuralist theories of 'assemblages', (Deleuze and Guattari, 1980), 'embodiment' (Merleau-Ponty, 1962), 'gaze' (Foucault, 1963), and 'gender identity' (Butler, 1990) as models for understanding gendered performativity within selfie production, these theories begin to form the view of selfies as a connection of overlapping biases, as well as nonhuman technological agencies and embodiment. According to Turkle $(1985,1997)$ online identity is emerging, decentred, and multiple, and 'playing with online personas' can shape a person's real life understanding of identity. A selfie producer continually seeks and adjusts visually what is important for their selfimage to suit an aspirational self that is constructed by the "likes" or positive comments on social media networks (Ardévol and Gómez-Cruz, 2012). Through this type of interaction, a sense of 
Volume 1, Issue 1: New Directions in Media Research 2015

achievement and success emerges, which will empower (Bustard, 2014) the person in the selfie by shaping his or her real-life understanding of self-identity (e.g., he or she will be more confident in real life) in terms of others' idealistic perception and wide acknowledgment (Nemer and Freeman, 2015).

The attachment and dependence on western cultural visual rhetoric manifests in the history of self-imaging prior to selfies reveals the background and cultural framework for thoughts, attitudes and behaviours surrounding selfie production. History and culture condition the semantic meaning. To accurately understand a cultural phenomenon such as selfies, it is necessary to take into account the powerful cultural attitudes that define the visual rhetoric for a culture. By looking at the dominant communications employed to instruct and explain the 'proper social practices', including self-portraiture, a cultural bias towards gendered performativity in selfie production begins to form. Selfies are digital objects that suture together the material with the digital post-humans are becoming.

\subsection{Gender Performance}

The core concept throughout this paper is the idea of gender construction as a performativity. This topic finds its origins in 'The Presentation of Self in Everyday Life' by Erving Goffman (1959), which illustrates his idea by using a metaphor of theatrical performance. In Goffman, all social interaction is created when people perform within specific situations, which they construct themselves and put in front of the other person they are socializing with. According to Goffman, this performance will change depending on who one's 'audience' is. One of the main insights from this theory (an insight which is key to the topic of selfie production) is the importance of having an agreed upon definition of the situation in a given interaction, in order to give the expected performance. The dominant cultural discourse regarding how gender ought to look and behave, given particular historical, geographical and cultural norms heavily influence the aesthetic choices in selfie production. The very nature of selfie production falls in line with the theory posited by Goffman (1959); it is a performance of everyday life, which is progressively narrated by the producer.

Foucault (1977) posits that it is the hegemonic discourse that establishes the dominant memory and attitudes of societies. That memory also forms the basis of rationality and reasoning within society. Dominant discourse is identified as the principal way in which governments and mainstream media discusses/presents topics of cultural interest and concern. As Foucault (1977) proposes, dominant ideologies perpetuate dominant discourses which in turn perpetuate dominant ideologies. Technologies of self-reflection, images of perceived heteronormativity in western art and 
Volume 1, Issue 1: New Directions in Media Research 2015

advertising, commercial photography involving gender- these are the discursive prequels to current methods of selfie performance (Warfield, 2014b). Empowerment and cultural programming are related ideas which, when considering the selfie, are strongly gendered.

With the act of making a selfie, women (as well as other marginalised people who are nonbinary) now have the authority to be the authors of their own visual stories (Trudy, 2015). Far from lifting the constraints of race, sex, gender, class, etc., the Internet has relentlessly underscored cultural imperatives geared toward heteronormativity 'whiteness', and heterosexuality. This is maintained through what Butler (1988) would describe as culturally repeated codes, those performative means of embodying ideological forces. We can see this at the level of the selfie, and through the imagery routinely used to represent heteronormative models of gender.

One example might be the 'male gaze' in film (Mulvey, 1989), television and fashion photography (Kilborne, 1979), which has long been assessed for the destructive effects on women, subjecting them to objectification, unattainable beauty standards, and demeaning visual rhetoric. Related to this, Angela McRobbie (2013) maps what she terms a 'double-entanglement' within popular cultural representations of heterosexual femininity, reflecting a co-existence of neoconservative values blended with commoditised conceptions of gender empowerment pushed by the dominant cultural discourse.

Poststructuralist research continues on in a similar manner within intersectional feminism, in that the emphasis is placed on identifying meanings that are context-specific and that relate to the varying discursive practices operating. Intersectional feminism was coined by the American legal scholar and critical race theorist Kimberlé Williams Crenshaw (1989) and is considered a theoretical and methodological tool appropriate for analysing how historically specific kinds of power differentials and/or structural sociocultural categorisations and unjust social relations (Lykke, 2010). Intersectional feminism has become the predominant way of conceptualizing the relationships between systems of oppression. These systems construct our multiple identities and our social locations in hierarchies of power and privilege (Carastathis, 2014).

The distinction from the past is that selfie producers will make the image themselves and 'how you should look' in a selfie will derive less from outside influences and more from apsirations and gratifications from selfie-producing on-line social networks (Pollen, 2014). Through 'selfie' selfportraits, the once marginalised and commoditised can now actively decide how much of themselves they will reveal to the world, and in which ways. People can take on the role of both photographer and subject, reclaiming the power of portrayal. For many marginalised users who are 
Volume 1, Issue 1: New Directions in Media Research 2015

suffering in a relatively severe living environment in Brazil, selfies are not a shallow way to show narcissism, fashion, and self-promotion and seek attention. Selfies empower the users to exercise free speech, practice self-reflection, express spiritual purity, improve literacy skills, and form strong interpersonal connections (Nemer and Freeman, 2015; Senft and Baym, 2015).

Equally, selfies have become an important solution to counteracting the negative effects involved with viewing manipulated commercial images. On Tumblr in particular, the trend of selfies has taken on intertwined connotations of body positivity and self-care. For example, Tumblr blogger Lindsey Bottos, a 21-year-old Baltimore-based artist who is a photography major and gender studies minor, runs a Tumblr page where she often uploads selfies as well as pictures of her work. Since starting the Tumblr in 2010, she has received hundreds of cruel anonymous messages (Bahadur, 2014). She turned the words of hate into a feminist art project where she screen-capped some of the hostile messages and posted them over the same pictures of herself that were the subject of abuse.

This seemingly simple act of taking her power back went viral online, and opened a larger dialog about the level of harassment women regularly face online (Drake, 2015). The first set of images, published on her Tumblr on Jan. $26^{\text {th }}$, has already been re-blogged over 98,000 times. The artist claims that she's received positive feedback since drawing attention to her abuse and is motivated to keep working with her ideas and evolving practical visual research (Bahadur, 2014).

People of various races, sexualities and body types post their selfies as a means of negotiating a positive relationship with their own physical forms. Instead of becoming self-critical and self-destructive, people use selfies as an assertion of the kind of reality they want for themselves. In 2013, within several social media networks, (Instagram, Twitter, Tumblr and Facebook), the \#FeministSelfie began trending and is still widely used as a way to share images of (mostly) women and girls that push back on gendered and racial expectations of beauty and presentation of self. In doing so, they reframe what "beautiful" and "woman" mean, among other things (Cole, 2015). Further to this, selfies can be seen as a uniting force for marginalised communities, for whom the act of re-blogging, liking, and commenting (supportively) on selfies has become an act of support and solidarity (Lasén and Gómez-Cruz, 2009).

\subsection{Embodiment}

Selfies are as much an assemblage of emotions as they are digital media objects. With mobile devices, we experience affect and agency, the representations of memories and identity we create, and the 'space of flow' nature of social networks (Castells, 1996). The idea of assemblages within 
Volume 1, Issue 1: New Directions in Media Research 2015

selfie production cannot be examined without beginning with the work of Deleuze and Guattari (1980), who hypothesise that fully material syntheses occurs not just with living objects, but inanimate ones as well. For them, the self is merely the collection point of infinite and random impulses and flows (to use their terms, lines of flight and machinic assemblages) that overlap and intercut with one another, but which only form the most transitory and dynamic connections.

As for what finds and creates these assemblages that are transitorily influential to us, Deleuze and Guattari analogise the botanical rhizome as a model (Deleuze and Guattari, 1980). The root of the rhizome remains subterranean, seeking out, in any direction, what feeds and serves it best. In selfie production, the selfie producer continuously establishes connections between semiotic chains (interpersonal attachments), organizations of power (social hierarchies), and circumstances relative to the photographer's culture, social interests, and efforts.

This process is similar to what Delueze and Guatarri refer to as 'becoming'. Becoming is not a process of imitation or analogy; it is a new way of being that is a function of influences rather than imitation (Deleuze and Guattari, 1980). The process of becoming involves removing undesired parts from their original meaning and bringing about new meanings. Theorist Brian Rotman (2008) posits that the concept of machinic assemblages is the basis of consciousness and mind. Rotman's elaboration of Deleuze and Guatarri's perspective is that media machines are not simply cold extensions of the body; they are mutating assemblages that include consciousness, memories and notions of identity. Selfies work in this way, as an embodied act that distributes and continually transforms the subject's concept of self.

What truly defines the selfie is not just the 'self' that is in it; it is also about the relationship between the self and technology. It is not unusual that mobile devices and the objects they create mediate our experience of the world. Gibson and Ingold (1995) illustrate, part of what makes humans a unique species of primate is the adaptation of technology to the body and mind. From the beginning of human history, we have evolved as beings that can make and use complex tools, use them to communicate in multifaceted ways, and engage in complex forms of social life more than any other species in the animal kingdom (Gibson and Ingold, 1995).

Visual technology mediates our relationship with the world by imposing itself between the eye and what it sees. Not only do we learn to see differently, but also we learn to act differently when our vision is mediated (Shinkle, 2014). As Shinkle observes, we incorporate the camera phone so thoroughly into our perceptual experience that it tends to withdraw as the focus of our attention. Rather than intervening between the self and the world it has become an essential part of our 
Volume 1, Issue 1: New Directions in Media Research 2015

encounter with the world (Kindberg et al., 2005). This phenomenon is sometimes referred to as 'proprioception'. Proprioception refers to the sense of the relative position of neighbouring parts of the body and the strength of effort being employed in movement. This sense enables us to incorporate tools within our bodily boundaries; as a result of proprioception, we can use tools with such fluency that they effectively stop being foreign objects and begin to act as extensions of the body (Kilner, 2014). This is the difference between seeing through a camera and seeing with it - a more empathic relationship that blurs the difference between the human and the technological worlds (Martin, 2014).

\subsection{Digital Visual Objects}

In order to appreciate how traditional digital aesthetics correspond with gender performativity within selfies, it is important to consider the established western attitude towards amateur photography. This section will discuss key aspects of aesthetics of photography in order to put into context the type of imaging distinctive to selfies and its in-built digital aesthetics. Selfies owe their origins in part to film photography. While the camera obscura predates the 1800 s, the invention of photography was essentially a $19^{\text {th }}$ century occurrence (Peres, 2007). At that time photographs had no clear social or cultural use for amateurs (Gernsheim, 1971). It was only with the advent of amateur photography in the late 1880s that photography came into its own as a form of visual expression that could provide social and cultural affirmations for the photographer and for the viewer (Newhall, 1972). These uses reinforced this self-consciousness of photography as an art and communication (Sontag, 1973). Photography was (and is) one of the most ubiquitous technologies in mass use and is an invention that arguably has had one of the biggest impacts on cultural life in the last two centuries (Peres, 2007).

The dominant way of seeing and judging images in the western world is one that reflects the way we are trained to see. The perception that continually dominates amateur photography by the general public is that photography is a precise representation of reality. This suspension of disbelief regarding photography is thought to be one of the remarkable aspects of the form; that is, its ability to combine with and alter the viewer's perception of identity. Roland Barthes (1980) said that photography, as a pictorial semiotic, is by no means a precise representation of reality. Barthes proceeds to distinguish between a characteristic that he calls the 'studium' and the 'punctum'. Studium implies the universal meaning in the photograph. The punctum is the private meaning; it is not easily communicated through language. Barthes feels this is the detail that attracts and holds the spectator's gaze. According to Barthes, the photograph is a duality (signifier and signified). Sontag (1977) reinforces this idea in her essay 'On Photography'. The dominant discourse on the semantics 
Volume 1, Issue 1: New Directions in Media Research 2015

of images floats around us from sources in mass media and we adopt their meanings into our consciousness in order to fit them into our culture (Lacan, 1977). In this same way, societies construct meanings, judgments and rules of proper use for selfie production.

The digital aesthetic has now been all around us for over a decade. This encapsulates the term referred to as 'post-digital' - a term that has recently come into use in the discourse of digital artistic practice (Cascone, 2000). 'Post-digital' does not aim to describe 'a life after digital', but rather attempts to describe the present-day opportunity to explore the consequences of living one's whole life immersed in digital aesthetic. The impact of living with and interacting with digital devices in everyday life has blurred the lines that once separated humans from machines. Manovich (1995) posits that when someone creates a digital image they are never doing it alone. It is always a symbiosis of individual and computer, creating together. The digital image is something that 'can exist in different, potentially infinite versions' (Manovich, 2001).

The selfie differs from its predecessor, traditional photography, in that it provides not only an agency with the subject, but an assemblage of both human consciousness and machine which jointly reconfigures the subjects (Rotman, 2008). The selfie captures and constructs personal and group biases, maintains social relationships, and expresses aspirational identity in a way not possible with the technologies which preceded it (Dolphijn and Tuin, 2012). Selfies produced and shared from mobile devices to social media form spaces where we may derive important cultural knowledge that facilitates the construction of our identities (Jenkins, 2006). Selfies shared across social media networks create a sense of 'fitting in' over time. They strengthen social bonds by sharing even the most seemingly mundane personal celebrations, and use social biases to construct models to understand the inner worlds of self and others (Wetherell, 2012).

\section{Conclusion}

What all these theories suggest is that images are not the only things that are being morphed, interconnected, and translated. Selfies become affective assemblages of a complete experience that influences the ephemeral, the imaginary, the biological, and the theoretical - in other words, materiality. These unions of dominant discourse within selfie production are conflicting. Through access to mobile apps that 'improve' images of faces, to a western normative ideal, the perceived normative ideal of faces in selfies establishes levels of identification, strengthens the relations and feeling of empowerment (Senft and Baym, 2015; Nemer and Freeman, 2015). 
Volume 1, Issue 1: New Directions in Media Research 2015

By authoring oneself online through selfie production, the subject also has the opportunity to shape the medium itself because what becomes part of their personal assemblages can differ from the tropes and conventions that came before (Ounstend, 2014a). In selfie production one can be coy, vulnerable and proud. They may show their pain, their humour their activism, or their eroticism, but the distinction from the past is that selfie producers will make the image themselves and "how you should look" in a selfie will evolve less and less from outside influences and more from inner rhizomes and gratifications from their social networks (Pollen, 2014). Selfie producers show others how they see themselves to be and these images will fly in the face of convention and the controlled demographic 'ideal' of gendered form in visual culture history. Through these selfportraits, people can take on the role of both photographer and subject. The marginalised take the power of portrayal back. They actively decide how much of themselves they will reveal to the world, and in which ways. These seemingly disposable selfies in turn have weighted value, and important potential for the feminist movement (Sweet, 2015).

\section{References}

Allen F. (2013) 'Selfie' Origins: Oxford Dictionaries 2013 Word of the Year First Used in Australian Online Forum. Available at: http://www.ibtimes.com.au/selfie-origins-oxford-dictionaries-2013word-year-first-used-australian-online-forum-1324116

Ardévol, E. \& Gómez-Cruz, E. (2012) Private body, public image: Self-portrait in the practice of digital photography. Revista de Dialectologia y Tradiciones Populares, 67, pp 181-208.

Bahadur, N. (2014) 'This Blogger's Response To Her Internet Haters Is Pitch Perfect', Available online: http://www.huffingtonpost.com/2014/02/03/lindsay-bottos-tumblr-anonymouscomments_n_4703344.html.

Barthes, R. (1980) Camera Lucida: Reflections on Photography. Translated from French by Hill \& Wang.

Butler, J. (1988) 'Performative Acts and Gender Constitution: An Essay in Phenomenology and Feminist Theory'. Theatre Journal, 40, pp 519-531.

Butler, J. (1990) Gender Trouble: Feminism and the Subversion of Identity (Routledge Classics), pp 276.

Cascone K. (2000) The Aesthetics of Failure: "Post-Digital" Tendencies in Contemporary Computer Music. Computer Music Journal MIT Press 24: pp 12-18.

Castells, M. (1996) Rise of the Network Society, Volume I: The Information Age : Economy, Society, and Culture (2nd Edition).Wiley-Blackwell.

Cole NL. (2015) The Selfie Debates, Part II. Available at: http://sociology.about.com/od/CurrentEvents-in-Sociological-Context/fl/The-Selfie-Debates-Part-II.htm. 
Volume 1, Issue 1: New Directions in Media Research 2015

Deleuze, G. \& Guattari, F. (1980) Thousand Plateaus: Capitalism and Schizophrenia. Translated from English by. London: The Athlone Press, London.

Oxford Dictionary http://www.oxforddictionaries.com/definition/english/selfie, Oxford University Press.

Dolphijn, R. \& Tuin, I.(2012) New Materialism: Interviews \& Cartographies. Translated from english by Open Humanities Press.

Drake B. (2015) The darkest side of online harassment: Menacing behavior. Available at: http://www.pewresearch.org/fact-tank/2015/06/01/the-darkest-side-of-online-harassmentmenacing-behavior/.

Foucault, M. (1963) The Birth of the Clinic: The Birth of the Clinic: An Archaeology of Medical Perception [eBook]. New York: Routledge.

Foucault, M. (1977) Discipline and Punish: The Birth of a Prison. New York: Random House.

Frosh P. (2015) Selfies | The Gestural Image: The Selfie, Photography Theory, and Kinesthetic Sociability. International Journal of Communication 9: pp 1607-1628.

Gibson, K. R. \& Ingold, T. (1995) Tools, Language and Cognition in Human Evolution.Cambridge University Press.

Goffman, E. (1959) The Presentation of Self in Everyday Life. London: Penguin.

Jenkins, H. (2006) Convergence Culture. New York: New York University Press.

Kilner, J. (2014) Part 4: The Curated Ego: What Makes a Good Selfie? Available online: https://www.youtube.com/watch?v=HPEjV-9BB5g [Accessed 2014-06-07 10:20:14].

Kindberg, T., Spasojevic, M., Fleck, R. \& Sellen, A. (2005) The ubiquitous camera: An in-depth study of camera phone use. Pervasive Computing, IEEE, 4, pp 42-50.

Lacan, J. (1977) The Mirror Stage as Formative of the I as Revealed in Psychoanalytic Experience(1949) Alan, S. New York: W.W. Norton \& Co.

Lasén, A. \& Gómez-Cruz, E. (2009) Digital Photography and Picture Sharing: Redefining the Public/Private Divide. Knowledge, Technology \& Policy, 22, pp 205-215.

Martin, R. (2014) Part 2: The Curated Ego: What Makes A Good Selfie? Available online: https://www.youtube.com/watch?v=-Hj860112pA [Accessed 2014-06-07 10:20:14]

McRobbie, A. (2013) 'Feminism, the Family and the New 'Mediated' Maternalism'. New Formations: A Journal of Culture/Theory/Politics, 80, pp 119-137.

Merleau-Ponty, M. (1962) Phenomenology of Perception: An Introduction (Routledge Classics).Routledge.

Mulvey, L. (1989) Visual and other pleasures. Basingstoke: Macmillan.

Nemer D and Freeman G. (2015) 'Selfies| Empowering the Marginalized: Rethinking Selfies in the Slums of Brazil'. International Journal of Communication 9: pp 1832- 1847. 
Volume 1, Issue 1: New Directions in Media Research 2015

Ounsted A. (2014) Selfies as People in Places, Not Objects in Spaces Available at: http://www.canadapress.org/canada/2014/03/22/selfies-people-places-objects-spaces/.

Pollen, A. (2014) Part 1: The Curated Ego: What Makes A Good Selfie? Available online: https://www.youtube.com/watch?v=sYCfeee8skY [Accessed 2014-04-30 12:03:06].

Rotman, B. (2008) Becoming Beside Ourselves: The Alphabet, Ghosts, and Distributed Human Beings, 1st edition. Duke University Press.

Senft, T. (2015) 'Studying Selfies: Issues, Methods, Pedagogy'., Association of Internet Researcher's Conference. Daegu, the Republic of Korea.

Senft TM and Baym NK. (2015) 'Selfies Introduction What Does the Selfie Say? Investigating a Global Phenomenon'. International Journal of Communication 9: pp 1588-1606.

Shinkle, E. (2014) Part 3: The Curated Ego: What Makes a Good Selfie? Available online: https://www.youtube.com/watch?v=-Y2oMiN5icA [Accessed 2014-06-07 10:20:14].

Sontag, S. (1977) On Photography.

Trudy (2015) What's Really Going On With The Sexist Backlash Against Selfies, GradientLairAvailable online: http://www.gradientlair.com/post/115395306478/sexist-backlash-against-selfies [Accessed 2015].

Walker Rettberg, J. (2014) Seeing Ourselves Through Technology March 2014,, Colloquium Presentation. University of Illinois Chicago, March 12th, 2014.

Warfield, K. (2014) Why I love Selfies and Why You Should Too (Damn it). Youtube: Kwantlen Polytechnic University.

Wetherell, M. (2012) Affect and Emotion: A New Social Science Understanding. London: SAGE.

\section{Biography}

Patricia Routh is a Doctoral Researcher at the University of Leicester, Department of Media and Communication whose research centres on digital media and visual culture. A creative professional with over 20 years involvement with lifestyle photography and digital content creation. She received a BFA from the Kansas City Art Institute and MSc from University of Hull, School of Arts and New Media. Her current Doctoral research investigates digital self-portraits (selfies), created and shared by mobile devices, to understand how groups of individuals often marginalised within the commoditised and hegemonic western visuality in society, engage with and distribute images of themselves. 
Contact author(s):

pr129@leicester.ac.uk

\section{Contact for(e)dialogue}

General inquiries at foredialogue@leicester.ac.uk

Editorial inquiries at foreditorial@leicester.ac.uk 